\title{
Milling Recovery and Quality of Combine Harvested Paddy: A Case Study in Batticaloa and Ampara Districts
}

\author{
R. Bawatharani ${ }^{*}$, D.N. Jayatissa ${ }^{1}$, D.A.N. Dharmasena ${ }^{1}$ and M.H.M.A. Bandara ${ }^{2}$
}

\author{
Postgraduate Institute of Agriculture \\ University of Peradeniya \\ Sri Lanka
}

\begin{abstract}
Grain quality directly affects the profitability of a crop. This study investigated the field operational conditions of combine harvesters with respect to the quality of the grain. A total of six brands of combine harvesters were tested in 10 different fields in Batticaloa and Ampara districts. The damages imposed on grains were determined based on the milling quality of the samples. The holistic view of data from farmers' field trials indicated that the combine forward speed, tip velocity of threshing drums and grain moisture content highly influenced the physical damages caused to the paddy grains during milling. Threshing unit tip velocity of the combine harvesters were found to be in the range of $10.35-$ $39.51 \mathrm{~m} / \mathrm{s}$. The tip velocity of $10.35 \mathrm{~m} / \mathrm{s}$ gave the lowest broken percentage of $15.38 \%$ and a higher head rice yield of $49.45 \%$. Relatively low percentages of broken rice of $19.32 \%$ and $27.45 \%$ were obtained at high forward speeds of 1.36 and $2.5 \mathrm{~m} / \mathrm{s}$, respectively. This could be due to the creation of cushioning effect on the grains by increasing feed rate. High impacting forces on the grains at increased tip velocities caused the grain fissures which decreased the quality of seed paddy. The lowest grain moisture content of $15.9 \%$ yielded a relatively high broken rice percentage of $33.98 \mathrm{~kg} / \mathrm{ha}$ at the tip velocity of $24.64 \mathrm{~m} / \mathrm{s}$. The highest grain damage of $39.94 \mathrm{~kg} / \mathrm{ha}$ was obtained during milling at the tip velocity of 39.51 $\mathrm{m} / \mathrm{s}$ at the moisture content of $20.9 \%$.
\end{abstract}

Keywords: Broken rice, head rice yield, milling, threshing drum, tip velocity

\section{INTRODUCTION}

Broken grains are hidden losses in combine harvesting and it is the essential criteria for the work quality of grain combine harvesters (Kutzbach and Quick, 1999). There is a concern among the farmers in Batticaloa and Ampara that they are financially penalized for selling combine harvested paddy than that of manually harvested paddy due to grain damage which in turn decreases the grain quality (Personal communication). Moreover, certain brands of combine harvesters are preferred by the farmers for better performance and quality of rice irrespective of the region and the rice variety cultivated.

As far as the combine owners are concerned, most of them have purchased the combine harvesters on lease in this region. Hence, they are in a position to pay the required amount of monthly instalment to the leasing company. As a consequence, the combine owners are

Department of Agricultural Engineering, Faculty of Agriculture, University of Peradeniya, Peradeniya, Sri Lanka

. Chief Engineer's Office, Department of Agriculture, Peradeniya, Sri Lanka

Corresponding author: bavatharani@yahoo.com.sg 
compelled to harvest as many paddy fields as possible in a single day. Therefore, the combine operators assigned by the combine owners are always in a hurry to leave the working field to get the job done in other fields in order to earn more money. As a result of this, they do neglect the prevailing crop and environmental conditions of the paddy field and finishes the task quickly without considering the manufacturer's recommendation, which in turn causes negative impacts on the grain quality.

Therefore, this study was carried out to determine the actual condition of the quality of the combine harvested paddy in various fields when different brands of combine harvesters were being operated. Since there were no previous studies in this aspect, a random field analysis was carried out to find out the real situation. As the combine harvesters crossed the paddy fields from Batticaloa to Ampara in Sri Lanka, this study can simulate the trend of paddy harvesting quality in the Eastern region.

\section{MATERIALS AND METHODS}

Since there were no primary data regarding the operation of combine harvesters in the field, this study was engaged in the data collection and observation of real field conditions regarding the use of combine harvesters. Therefore, field evaluations were carried out in farmers' fields during Yala 2012 as per RNAM test code procedures to broaden the scope of the experiment in real field conditions. A total of six brands of combine harvesters were tested in 10 different fields in Batticaloa and Ampara districts with Indica type paddy varieties. Data were collected from different fields, finding combine harvesters randomly and collecting grain samples from the grain tank of each combine harvester in three replicates. In addition to this, an area of $1 \mathrm{~m}^{2}$ was harvested manually to obtain manually harvested grain samples. The quality of the paddy was determined in terms of head rice yield after milling. The head rice yield is calculated as the head rice per weight of the paddy sample milled.

\section{Measurement of crop and machine operating parameters}

The key parameters for header losses in the operation of rice combine harvesters were analyzed; namely, the grain moisture content was determined using 'Satake' grain moisture meter, threshing drum diameter was measured using a measuring tape, threshing drum pulley speed was determined using an optical handheld tachometer (HIOKI 3404) and the speed of the combine harvesters were determined using a stop watch and a measuring tape.

\section{Feed rate of combine harvesters}

The feed rate was calculated by Eq. 1 as suggested by Yasin (1989).

$$
F R=\frac{F_{x} W x Y}{C}
$$

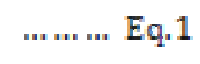

where,

$$
\begin{aligned}
& F R-\text { Feed rate }(\mathrm{t} / \mathrm{h}) \\
& F-\text { Forward speed }(\mathrm{km} / \mathrm{h}) \\
& W-\text { Cutting width }(\mathrm{m}) \\
& Y-\text { Weight of crop }(\mathrm{t} / \mathrm{ha})
\end{aligned}
$$




$$
C-\text { Constant }=10
$$

\section{The yield estimation $(Y)$}

It was determined by throwing a quadrate made of stiff steel rods measuring $0.71 \mathrm{~m}$ by 0.71 $\mathrm{m}\left(0.5 \mathrm{~m}^{2}\right)$ area randomly in three sample areas in each plot and the panicles enclosed in such area were harvested manually and weighed. The mean weight of crop was used in Equation 1 to determine the feed rate.

\section{Paddy storage and drying}

Immediately after harvest, the samples were transported to the Department of Agric. Engineering at the Eastern University in polythene packets holding about $1 \mathrm{~kg}$. The foreign matters were manually cleaned and air dried to a moisture content of $13.5 \%$ before storage.

\section{Milling process}

Milling process was adopted for both combine harvested paddy samples as well as for manually harvested samples. Dehusking was done to obtain brown rice at the Institute of Postharvest Technology in Anuradhapura. A paddy sample of $250 \mathrm{~g}$ was taken in three replicates from each bag and de-husked using a Satake paddy sheller (Satake Engineering Co. Ltd. Tokyo, Japan) in three replicates.

Brown rice was then milled for $30 \mathrm{sec}$ using a McGill Nr 2 mill (Rapsco, Brookshire, Texas). The total weight of the milled paddy was measured to determine the percent loss in weight of brown rice on milling. Broken grains were manually separated and total milled rice and head rice yields were calculated as percentage of paddy used for milling.

\section{Head rice yield percentage}

The percentage of head paddy was calculated using the Eq. 2 .

$$
\text { Head rice yeld }(\%)=\frac{\text { Weight of whole grains }}{\text { Weight of padily sample }} \times 100
$$

\section{Broken percentage}

The percentage of broken rice was calculated using the Eq. 3 .

$$
\text { Brokens }\left(\phi^{\prime}\right)=\frac{\text { Woight of broken groins }}{\text { Weight of paddy sample }} X 100
$$

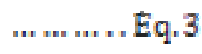

\section{Germination test}

In order to determine seed quality of combine harvested paddy, fifty seeds were taken from the packets containing the sample, to be grown in petri dishes with ambient light and 
temperature. The percentage of germination was expressed on the basis of normal seedlings using Eq. 4 suggested by Agarwal (1985).

$$
\text { Germination } \%=\frac{\text { Number of normal, vigorous and healthy seedings }}{\text { Total number of seds }} 100_{\text {an wa a }} \mathrm{Eq}, 4
$$

\section{RESULTS AND DISCUSSION}

Important specifications of the combine harvesters evaluated in this study are given in Table 1. Further the details of different combine harvesters evaluated with respect to different tip velocities to harvest paddy are given in Table 2 . Although the field environmental conditions as well as the crop conditions were considerably different, the discussion was made focusing only on certain machine operational conditions that are relevant to the study. Threshing drum impact velocity (tip velocity) ranged from $10.35 \mathrm{~m} / \mathrm{s}-39.51 \mathrm{~m} / \mathrm{s}$ with different varieties of paddy at varying harvesting grain moisture contents from $15.9 \%$ to $27.0 \%$. It was realized that the combine operators employed different threshing tip velocities irrespective of the crop conditions.

Table 1. Important specifications of the tested combine harvesters

\begin{tabular}{|c|c|c|c|c|c|c|}
\hline Parameters & Brand 1 & Brand 2 & Brand 3 & Brand 4 & Brand 5 & Brand 6 \\
\hline Structure & $\begin{array}{l}\text { Track } \\
\text { type full } \\
\text { feeding }\end{array}$ & $\begin{array}{l}\text { Tyre } \\
\text { type full } \\
\text { feeding }\end{array}$ & $\begin{array}{l}\text { Track } \\
\text { type full } \\
\text { feeding }\end{array}$ & $\begin{array}{l}\text { Track } \\
\text { type full } \\
\text { feeding }\end{array}$ & $\begin{array}{l}\text { Track } \\
\text { type full } \\
\text { feeding }\end{array}$ & $\begin{array}{l}\text { Track } \\
\text { type full } \\
\text { feeding }\end{array}$ \\
\hline Overall dimensions $(\mathrm{mm})$ & $\begin{array}{l}4500 \times 250 \\
0 \times 2650\end{array}$ & $\begin{array}{l}7590 \times 43 \\
43 \times 3454\end{array}$ & $\begin{array}{l}4700 \times 230 \\
0 \times 2700\end{array}$ & $\begin{array}{l}5855 \times 262 \\
0 \times 2905\end{array}$ & $\begin{array}{l}4800 \times 217 \\
5 \times 2740\end{array}$ & $\begin{array}{l}4500 \times 205 \\
0 \times 2650\end{array}$ \\
\hline Engine power (hp) & 60.0 & 48.9 & 49.0 & 60.0 & 66.1 & 60.0 \\
\hline Cutter bar width (m) & 2.00 & 3.95 & 2.00 & 2.10 & 2.00 & 2.08 \\
\hline $\begin{array}{l}\text { Thresher drum diameter } \\
(\mathrm{mm})\end{array}$ & 550.0 & 479.0 & 304.8 & 450.0 & 620.0 & 304.8 \\
\hline Grain tank capacity (kg) & 450 & 1050 & 450 & 650 & 600 & 450 \\
\hline
\end{tabular}

Table 2. Threshing tip velocities employed in harvesting different paddy varieties

\begin{tabular}{ccccccc}
\hline $\begin{array}{l}\text { Fiel } \\
\text { d } \\
\text { no. }\end{array}$ & $\begin{array}{c}\text { Type of } \\
\text { combine } \\
\text { evaluated }\end{array}$ & $\begin{array}{c}\text { Drum tip } \\
\text { velocity } \\
(\mathbf{m} / \mathbf{s})\end{array}$ & $\begin{array}{c}\text { Type of } \\
\text { drum }\end{array}$ & $\begin{array}{c}\text { Combine } \\
\text { forward } \\
\text { speed }(\mathbf{m} / \mathbf{s})\end{array}$ & $\begin{array}{c}\text { Feed } \\
\text { rate } \\
(\mathbf{t} / \mathbf{h})\end{array}$ & $\begin{array}{c}\text { Harvesting } \\
\text { moisture } \\
\text { content \% }(\mathbf{w b})\end{array}$ \\
\hline 1 & Brand 1 & 20.75 & Spike tooth & 0.31 & 1.80 & 22.8 \\
2 & Brand2 & 33.93 & Spike tooth & 1.10 & 9.04 & 27.0 \\
3 & Brand 2 & 39.51 & Spike tooth & 0.59 & 8.04 & 20.3 \\
4 & Brand 1 & 35.44 & Spike tooth & 2.50 & 12.20 & 20.9 \\
5 & Brand 3 & 10.35 & Spike tooth & 0.29 & 2.43 & 21.3 \\
6 & Brand 4 & 20.43 & Spike tooth & 0.86 & 5.98 & 19.1 \\
7 & Brand 5 & 24.64 & Spike tooth & 0.70 & 5.35 & 15.9 \\
8 & Brand 6 & 25.96 & Spike tooth & 1.36 & 11.52 & 17.5 \\
9 & Brand 5 & 24.41 & Spike tooth & 0.46 & 3.17 & 27.4 \\
10 & Brand 1 & 23.13 & Spike tooth & 0.74 & 2.51 & 20.6 \\
\hline
\end{tabular}




\section{Effect of tip velocity on head rice yield}

When comparing fields 1 and 10, the drum tip velocity varied from $20.75 \mathrm{~m} / \mathrm{s}$ to $23.13 \mathrm{~m} / \mathrm{s}$, respectively with Brand 1 combine and the head rice recovery was lower in field 10. Despite a higher feed rate of $2.51 \mathrm{t} / \mathrm{h}$ in field 10 , grain moisture content was comparatively low (20.6\%) and the impact force on the grains was higher due to higher impact velocity of the drum in field 10 (Table 2). Therefore, there was a reduction in the head rice yield from $45.7 \%$ in field 1 to $42.04 \%$ in field 10 .

In comparison of site 9 with 10, the drum impact velocities were found to be $24.41 \mathrm{~m} / \mathrm{s}$ and $23.13 \mathrm{~m} / \mathrm{s}$ respectively. However, when compared to site 10 , the head rice yield was found to be higher in field 9, in spite of the higher drum tip velocity of brand 5 combine. It was observed that the plant density was higher in field 9 than that in field 10, so that the feed rate was found to be $3.17 \mathrm{t} / \mathrm{h}$ in field 9 with brand 5 combine and it was $2.51 \mathrm{t} / \mathrm{h}$ in field 10 with brand 1 combine (Table 2). As a result of this, the grains were prevented from the higher impact velocity of the drums due to the cushioning effect of the grains in field 9 and hence the head rice yield was higher. This is due to the dense layer of material passing between cylinders and concave bars at high feed rates which provide more production and reducing the repeated impacts by the cylinder bars (Helmy et al., 1995).

The tip velocities were $24.64 \mathrm{~m} / \mathrm{s}$ and $24.41 \mathrm{~m} / \mathrm{s}$ in field 7 and 9 with the feed rates of 5.35 $\mathrm{t} / \mathrm{h}$ and $3.17 \mathrm{t} / \mathrm{h}$ respectively with brand 1 combine. In comparison of these two sites, the forward speed of the combine in field 7 was found to be $0.7 \mathrm{~m} / \mathrm{s}$ whereas it was $0.46 \mathrm{~m} / \mathrm{s} \mathrm{in}$ field 9. As a consequence, comparatively higher feed rate was observed in field 7 which in turn resulted in comparatively higher head rice yield of $38.72 \mathrm{~kg} / \mathrm{ha}$ when compared to site 9 as a result of the so called cushioning effect. On the other hand, it was observed that field 9 underwent rewetting of grains before harvesting due to rains, so that the moisture content of the grains increased to $27.4 \%$ at the time of harvest which might have reduced the head rice yield to $38.72 \%$ as well (Figure 1). Several researchers have observed that rewetting or adsorption of moisture, by paddy kernels will reduce the head rice yield if the paddy has dried below certain variety specific moisture content (Seibenmorgen and Jindal, 1986; Calderwood, 1984).

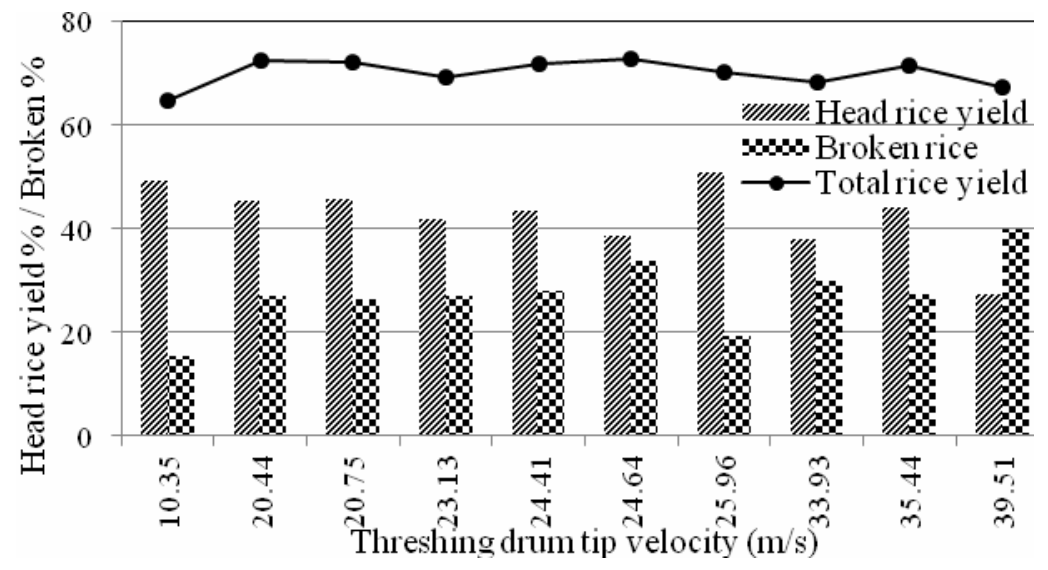

Fig. 1. Head rice yield and percentage of broken rice from combine harvested paddy 
When comparing sites 7 and 8, the tip velocities recorded were $24.64 \mathrm{~m} / \mathrm{s}$ with brand 5 and $25.96 \mathrm{~m} / \mathrm{s}$ with brand 6 . As discussed above, the higher head rice yield of $50.88 \mathrm{~kg} / \mathrm{ha}$ was obtained in field 8 even with the higher impact velocity of $25.96 \mathrm{~m} / \mathrm{s}$. This is again due to the cushioning effect of the harvested materials at a very high feed rate of $11.52 \mathrm{t} / \mathrm{h}$ in field 8 . But site 7 had lesser feed rate of $5.35 \mathrm{t} / \mathrm{h}$ at which the cushioning effect was comparatively lower when compared to site 8 , leading to lower head rice yields of $38.21 \mathrm{~kg} / \mathrm{ha}$.

However, it has been observed that when the tip velocity was at $33.93 \mathrm{~m} / \mathrm{s}$ in field 2 with brand 2 combine, the head rice yield was lower than that in field 8 with the impact velocity of $\quad 25.96 \mathrm{~m} / \mathrm{s}$. This could be due to the impact force of the drum on the grains. At this context, it is considered that the cushioning effect was negligible with the feed rate of 9.04 $\mathrm{t} / \mathrm{h}$ in field 2, since the drum tip velocity of the brand 2 combine was higher. But in contrast, the impact velocity of $35.44 \mathrm{~m} / \mathrm{s}$ was recorded in field 4 with brand 1 combine and the head paddy yield was higher $(44.11 \mathrm{~kg} / \mathrm{ha})$ than that in field 2 because in field 4 the brand 1 combine travelled with a forward speed of $2.5 \mathrm{~m} / \mathrm{s}$ which resulted in by far a higher feed rate of $12.2 \mathrm{t} / \mathrm{h}$. Hence, with this highest feed rate there might be less damages to the gains and as a result of this the head rice yield was higher in field 4 with the brand 1 combine than that in field 2 with brand 2 combine.

The brand 2 combine operated in field 3 imposed a tip velocity of $39.51 \mathrm{~m} / \mathrm{s}$ on the grains with a forward speed of $0.59 \mathrm{~m} / \mathrm{s}$ and $8.04 \mathrm{t} / \mathrm{h}$ of feed rate at $20.3 \%$ grain moisture content. The feed rate of $8.04 \mathrm{t} / \mathrm{h}$ might have not contributed enough to the cushioning effect so that the head rice yield was $27.57 \mathrm{~kg} / \mathrm{ha}$ which was lower than the head rice recovery in field 4 with the brand 1 combine. Therefore in general, increasing tip velocities caused increased broken rice percentage or less head rice yield during milling, which could be attributed to the increased impact force on the grains during harvesting leading to internal cracks in the kernels (Srivastava et al., 1993). Moreover it is considered that at higher drum impact velocities, the peripheral speed at the tip of peg tooth is increased, and leading to more impact on the grains. But, grain damage depends not only on the threshing tip velocity but also on the crop varieties, grain moisture content, feed rate etc (Eimer, 1988). It is apparent that the strength of grains at different paddy varieties with respect to impact force has been different, which might have caused irregularities in the observed head rice yield to a considerable extent.

\section{Manually harvested vs combine harvested head rice yields}

In general the recommended tip velocity for peg-tooth type drums should be about $12-16 \mathrm{~m} / \mathrm{s}$ (Training manual for harvesting, IRRI). But, the observed tip velocities in all the tested combine harvesters were beyond the recommended range. However, other machine operating factors such as the forward speed exerted an effect on the quality of the threshed paddy.

The results revealed that comparatively acceptable head rice yields were obtained at tip velocities between $10.35-20.75 \mathrm{~m} / \mathrm{s}$. A Comparatively lower percentage of head rice yield of $27.57 \%$ was obtained at tip velocity of $39.51 \mathrm{~m} / \mathrm{s}$ (Figure 2). However, several factors are known to affect the quality of harvested paddy. It is generally known that a large variation in kernel moisture content can exist among kernels on a plant and among plants in a field (Chau and Kunze, 1982). 


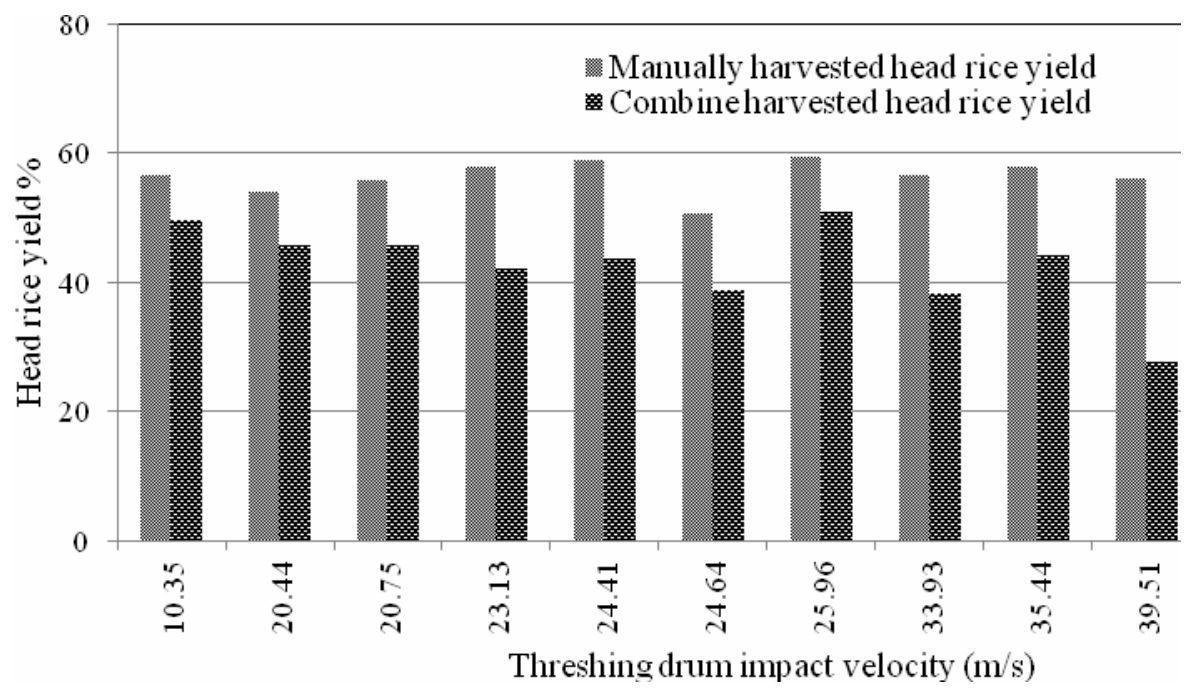

Fig. 2. Head rice recovery from different combines with respect to manual harvesting

The grain moisture contents of the harvested paddy varieties in field 6,7 and 8 ranged between 15.9 - 19.1\% which resulted in fairly lower head rice yields. This finding is supported by the findings of Geng et al. (1984), who reported that the maximum head rice yield was obtained when harvested variety specific moisture content in the range of about $20 \%$ - 27\%. Smith et al. (1938) also found that the optimum harvest moisture content in order to maintain high total yield and head rice yield was between $23 \%$ to $28 \%$ and concluded that the high moisture content paddy kernels were immature and when dried were light in weight, chalky and did not mill well.

\section{Broken rice percentage in combine and manual harvesting}

Figure 3 shows the effect of tip velocity on the grain damage during milling. The higher percentage of grain damage was $39.94 \%$ at a tip speed of $39.51 \mathrm{~m} / \mathrm{s}$, whereas the lowest was $15.38 \%$ at a tip speed of $10.35 \mathrm{~m} / \mathrm{s}$. This increase was due to higher impact levels imparted to the crop during threshing at higher tip speeds. The fact that increases in tip speed is accompanied by more grain mechanical damage is in accordance with results obtained by other research workers Mohtasebi et al. (2006); Srivastava et al. (1995) and Wang et al. (1988). 


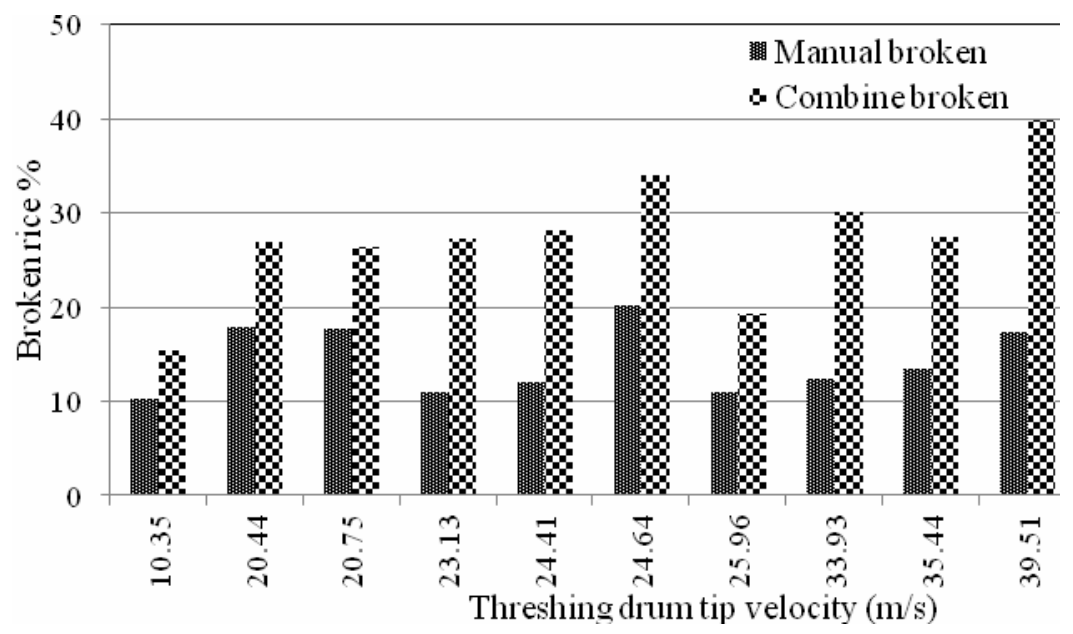

Fig. 3. Variation in broken paddy percentage from different combines with respect to manual harvesting

The forward speed of different combine harvesters had a distinct effect on decreasing the grain damage loss (Figure 4). A decreasing grain damage trend was observed from forward speeds of $0.29 \mathrm{~m} / \mathrm{s}$ to $2.5 \mathrm{~m} / \mathrm{s}$. This trend of decreasing grain damage might be due to increasing feed rate which created cushioning effect resulting in less impact force on the individual grains and hence less grain damage. The decrease in grain damage with an increase in feed rate has also been documented by Sabir et al. (2005) and Vas and Harrison, (1969). The forward speeds of the combine harvesters observed in field 6 and 7 are more or less in accordance with the findings of Bawatharani et al. (2013), which resulted in comparatively lower broken rice percentage as well. This implies that the forward speeds of $0.74 \mathrm{~m} / \mathrm{s}$ and $0.86 \mathrm{~m} / \mathrm{s}$ in field 6 and 7 could be suitable in terms of reducing grain breakage as well.

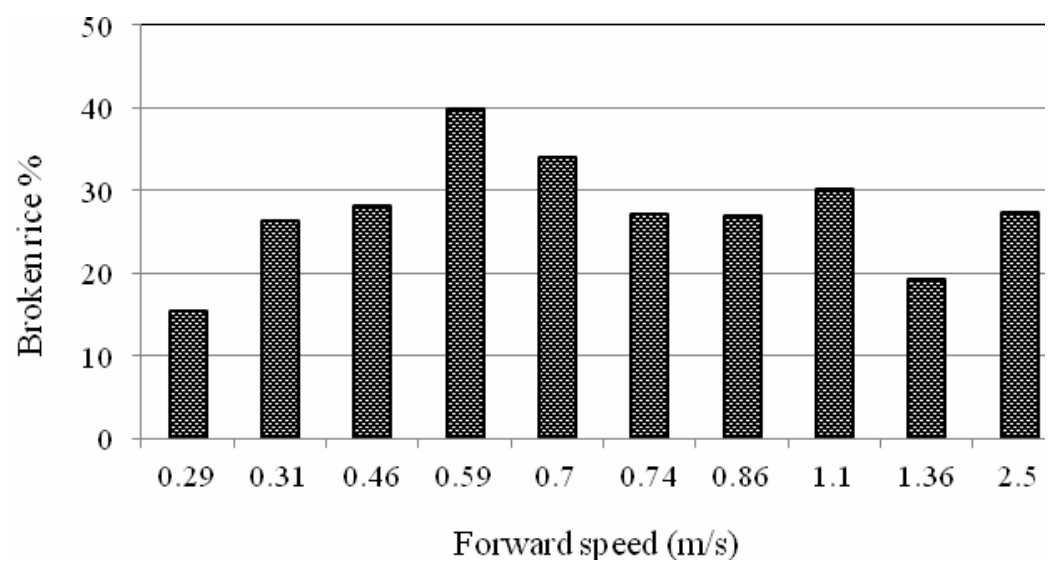

Fig. 4. Variation in broken rice percentage from different combines with respect to forward speed 


\section{CONCLUSIONS}

The variations in broken paddy were in the range of $15.38 \%$ at tip velocities of $10.35 \mathrm{~m} / \mathrm{s}$ and at $20.3 \%$ moisture content to $39.94 \%$ at a tip velocity of $39.51 \mathrm{~m} / \mathrm{s}$ at $20.3 \%$ grain moisture content across the tested fields. The tip velocity from $10.35 \mathrm{~m} / \mathrm{s}$ gave the lowest broken percentage of $15.38 \%$ and a higher head rice yield of $49.45 \%$.

However, the grain breakage also depends on grain moisture content and other operating conditions of the combine. Therefore, each variety needs its own tip velocity and forward speed for the optimum milling yield.

The forward speed of the harvester had a distinct effect on decreasing the grain damage. Relatively lower percentage of broken rice of $19.32 \%$ and $27.45 \%$ were obtained at forward speeds 1.36 and $2.5 \mathrm{~m} / \mathrm{s}$, respectively due to the cushioning effect at increased feed rates with acceptable head rice recoveries of 50.88 and $44.11 \%$, respectively.

The grain moisture content together with tip velocity affected the amount of grain breakage of all paddy varieties. A lower grain moisture content of $15.9 \%$ yielded a higher broken rice percentage of $33.98 \%$ at a higher tip velocity of $24.64 \mathrm{~m} / \mathrm{s}$. The most damaged grain of $39.94 \%$ was obtained during milling at tip velocity of $39.51 \mathrm{~m} / \mathrm{s}$ with a moisture content of $20.9 \%$.

\section{RECOMMENDATION}

It is obvious from this study that the brand of the combine did not influence in the loss of grain quality, but the operational as well as the crop and environmental factors influence more on it.

As the manufacturer's recommendations provide maximum and minimum possible operational condition of the combine harvesters, it doesn't make any sense to the operator in terms of the prevailing crop and environmental conditions in the field. This seems to be the most important reason for the poor quality of combine harvested paddy. Therefore, it is recommended to adjust the combine operating conditions based on the crop conditions to get better quality of rice.

\section{REFERENCES}

Agarwal, R.L. (1985). Seed Technology. Oxford and IBM publishing Co. Delhi.

ASABE. (2005). Terminology for combines and grain harvesting (S343.3). In: ASABE standards. American Society of Agricultural and Biological Engineers. St Joseph, MI.

AskariAsli-Ardeh, E. and Abbaspour-Gilandeh, Y. (2008). Investigation of the effective factors on threshing loss, damaged grains percent and material other than grain to grain ratio on an auto head feed threshing unit. American Journal of Agricultural and Biological Sciences, 3(4), 699 - 705. 
Bainer, R., Kepner, R.A. and Barger, E.L. (1960). Principles of Farm Machinery. Wiley and Sons, New York.

Banaszek, M.M. and T.J. Siebenmorgan. (1990). Head rice yield reduction rates caused by moisture adsorption. Transactions of the ASAE, 33(4), 1263 - 1269.

Bawatharani, R., Jayatissa, D.N., Dharmasena, D.A.N. and Bandara, M.H.M.A. (2013). Impact of reel index on header losses of paddy and performance of combine harvesters. Tropical Agricultural Research, 9 (1). 1 - 13.

Calderwood, D.L. (1984). Milling yield of rough rice blended at different moisture contents. Transactions of the ASAE 27(1), 248 - 249, 254.

Caspers, L. (1966). Influence of concave clearance and construction on threshing performance. Transactions of the ASAE, 16(6), 220 - 226.

Chau, N.N. and Kunze, O.R. (1982). Moisture content variation among harvested grains. Transactions of the ASAE, 25(4), 1037 - 1040.

Chinsuwan, W., Pongjan, N., Chuan-Udom, S., and Phayom, W. (2003). effects of feed rate and threshing speed on performance of axial flow rice thresher. TSAE Journal, 10(1), 9 - 14.

Eimer, M. (1988). Einfluss von Schnitzeipunkt und Feuchte des Erntegutes auf die Arbeitsqualitatdes Schlagleistendreschwerks. In: VDI-MEG Kolloquium Landtechnik Mahdrescher, Tagung Hohenheim, 25/26 April, 1988, Stuttgart, 93-106. In: Agronomy Research 6 (Special issue), 367 - 376, 2008.

Geng, S., Williams, J.F. and Hill, J.E. (1984). Harvest moisture effects on rice milling quality. California Agric. Exp. Stn., Berkeley, 38(11/12), 11 - 12.

Hanna, H. M., and G. R. Quick. (2007). Grain harvesting machinery design. In: Hand Book of Farm, Dairy and Food Machinery, 93-111. M. Kutz, ed.: William Andrew, Inc., Delmar, NY, USA.

Helmy, M.A., Gomaa, S.M., Hindey, F.I. and Abushieshaa, R.R. (1995).Comparative study on two different rice combine harvesting machine. Misr. J. Agric. Eng. 12(2), 479 - 495.

Kutzbach, H. D. and G. R. Quick. (1999). Harvesters and threshers grain. In: CIGR Handbook of Agricultural Engineering, Volume III, Plant Production Engineering. ed.: The International Commission of Agricultural Engineering. American Society of Agricultural Engineers. St Joseph.

Mohtasebi, S.S., Behroozi-Lar, M., Alidadi, J. and Besharti, K. (2006). A new design for grain combine thresher. Int. J. Agric. Biol., 8, 680 - 683.

Sabir, M.S., Igbal, M. and Yasin, M. (2005). Influence of selected combine and crop parameters on kernel damage and threshability of wheat. Pak. J. Agri. Sci. 212 (3-4), 112 116.

Siebenmorgen, T.J. and Jindal, V.K. (1986). Effects of moisture adsorption on the head rice yields of long grain rough rice. Transactions of the ASAE, 29(6), 1767 - 1771. 
Siebenmorgen, T.J., Perdon, A.A, Chen, X. and Mauromous, A. (1998). Relating rice milling quality changes during adsorption to individual kernel moisture content distribution. Cereal Chemistry. 75(1), $129-136$.

Smith, W.D., Deffes, J.J., Bennet, C.H., Adair, C.R., and Beachell, H.M. (1938). Effect of date of harvest on yield and milling quality of rice. U.S. Department of Agriculture Circular No. 484.

Srivastava, A.K., Goering, C.E and Rohrbach, R.P. (1993). Engineering Principles of Agricultural Machines. ASAE Text book. No. 6, St.Joseph MI.

Srivastava, A.K., Goering, C.E. and Rohrabach, R.P. (1995). Engineering Principles of Agricultural Machines.ASAE- Text Book Number 6.Published by American Society of Agricultural Engineers. Pamela Devore-Hansen, Editor, Books \& Journal. USA.

Srivastava, A.K., Goering ,C.E., Rohrbach, R.P. and Buckmaster, D.R. (2006). Chapter 12, Grain harvesting. In Engineering Principles of Agricultural Machines. 2nd ed., 403 - 436. St.Joseph, Michigan, ASABE.

Training manual for harvesting. Agricultural Engineering unit. International rice research institute (IRRI) pp: 12-14. (on line). (Accessed on 17.04.2013). Available at http://www.knowledgebank.irri.org/.../Training \%20Manual\%20Harvesting.doc.

Vas, F.M. and Harrison, H.P. (1969).The effect of selected mechanical threshing parameters on kernel damage and threshability of wheat. Canadian Agricultural Engineering. 11(2), 83 $-87$.

Wang, G., Zoerb, G.C. and Hill, L.G. (1988). A combine separating loss monitor. Transactions of the ASAE. 313, 692 - 694.

Yasin, M. (1989). Effect of combine and crop parameters on wheat recovery. Unpublished M.Sc (Hons.) Thesis. Department of Agric. Engineering, University of Agriculture, Faisalabad. Pakistan. 